\title{
Effects of long-term cyclosporin therapy on gingiva of rats - analysis by stereological and biochemical estimation
}

\section{Efeito do longo período de terapia com ciclosporina na gengiva de ratos - análise estereológica e bioquímica}

\author{
Luis Carlos Spolidorio* \\ Denise Madalena Palomari Spolidorio* \\ Marinella Holzhausen** \\ Patricia Oehlmeyer Nassar** \\ Carlos Augusto Nassar**
}

\begin{abstract}
Cyclosporin A (CsA) is used as an immunosuppressive agent and its prominent side effect is the induction of gingival overgrowth, which remains a significant problem. The risk factors appraised include the duration of treatment. However, there are no stereological and biochemical studies exploring the effects of long-term CsA therapy on gingival tissue. The purpose of the present study was to investigate the level of TGF- $\beta_{1}$ in saliva and describe the densities of fibroblasts and collagen fibers in the gingival tissue of rats treated with CsA for long periods. Rats were treated for $60,120,180$ and 240 days with a daily subcutaneous injection of $10 \mathrm{mg} / \mathrm{kg}$ of body weight of CsA. At the end of the experimental periods, saliva was collected for the determination of TGF- $\beta_{1}$ levels. After histological processing, the oral epithelium and the connective tissue area were measured as well as the volume densities of fibroblasts (Vf) and collagen fibers (Vcf). After 60 and 120 days of CsA treatment, there was a significant increase in Vf and Vcf as well as a significant increase in TGF- $\beta_{1}$ levels. After 180 and 240 days, reduction in the gingival overgrowth associated with significant decreases in the level of TGF- $\beta_{1}$, and also decreased Vf and Vcf, were observed. The data presented here suggest that after long-term therapy, a decrease in TGF- $\beta_{1}$ levels occurs, which might contribute to an increase in the proteolytic activity of fibroblasts in the gingiva, favoring the normality of extracellular matrix synthesis.
\end{abstract}

DESCRIPTORS: Cyclosporine; Stereological analysis; Biochemical analysis; Gingival hyperplasia.

\begin{abstract}
RESUMO: A ciclosporina A (CsA) é usada como um agente imunossupressor e promove efeitos colaterais como o crescimento gengival que permanece um problema significante. Alguns fatores de risco podem aumentar esses efeitos, como a duração do tratamento. Ainda não há estudos estereológicos e bioquímicos explorando os efeitos de um longo periodo de terapia com CsA no tecido gengival. O objetivo do presente estudo foi investigar o nivel de TGF- $\beta_{1}$ na saliva e descobrir a densidade de fibroblastos e fibras colágenas no tecido gengival de ratos tratados por um longo periodo com CsA. Os ratos foram tratados por 60, 120, 180 e 240 dias com injeções subcutâneas diárias de $10 \mathrm{mg} / \mathrm{kg}$ de peso corporal de CsA. Ao final dos períodos experimentais, a saliva era coletada para determinação do TGF- $\beta_{1}$. Após o processamento histológico, o epitélio oral e a área do tecido conjuntivo foram medidos, bem como a densidade volumétrica dos fibroblastos (Vf) e das fibras colágenas (Vcf). Após 60 e 120 dias de tratamento com CsA ocorreu um significante aumento de Vf e Vcf, bem como aumento significante de TGF- $\beta_{1}$. Após 180 e 240 dias, houve redução do crescimento gengival associada com decréscimo significante do nível de TGF- $\beta_{1}$, e também diminuição observada de Vf e Vcf. Os dados presentes neste estudo sugerem que, após longo período de terapia, ocorre uma diminuição do nível de TGF- $\beta_{1}$, o que deve contribuir para um aumento na atividade proteolítica dos fibroblastos na gengiva, favorecendo a normalidade da sintese da matriz extracelular.

DESCRITORES: Ciclosporina; Análise estereológica; Análise bioquímica; Hiperplasia gengival.
\end{abstract}

\section{INTRODUCTION}

Cyclosporin A (CsA) is a cyclic undecapeptide that was initially isolated from the fungus Tolypocladium inflatum gams ${ }^{12}$. The use of CsA as an immunosuppressant has revolutionized organ transplantation, which has become the manage- ment of choice for many patients with chronic and life-threatening conditions ${ }^{8}$. CsA has also been used for the treatment of type 2 diabetes, rheumatoid arthritis, psoriasis, multiple sclerosis, malaria, sarcoidosis, and several other diseases with an

\footnotetext{
*Adjunct Professors, Department of Oral Pathology; ${ }^{*}$ Graduate Students - School of Dentistry of Araraquara, São Paulo State University.
} 
Spolidorio LC, Spolidorio DMP, Holzhausen M, Nassar PO, Nassar CA. Effects of long-term cyclosporin therapy on gingiva of rats - analysis by stereological and biochemical estimation. Braz Oral Res 2005;19(2):112-8.

immunological basis ${ }^{7,8,12}$. CsA's main side effects include nephrotoxicity, hepatic dysfunction, neurological disturbances and hypertension ${ }^{12,18}$. The most prominent side effect of CsA therapy in oral tissues is gingival overgrowth ${ }^{11,19,21}$.

Alterations in fibroblasts, together with increased collagen production and/or degradation, are considered to be the cause of this overgrowth $^{11,15,26}$. Alterations in tissue metabolism caused by CsA may be dependent on many variables such as patient's gender, CsA dosage and serum level, and concurrent drug therapy ${ }^{10,13,22,23}$.

Another factor that must be considered is the duration of therapy ${ }^{17}$. A longitudinal study by Montebugnoli et al. ${ }^{17}$ (2000) demonstrated the relevant role of time in reducing gingival overgrowth in heart transplant patients undergoing CsA therapy.

Montebugnoli et al. ${ }^{17}$ (2000) suggested that gingival overgrowth necessarily develops in responders within 6 months of transplantation, and that, in most subjects, it may be a time-related side effect probably due to a progressive reduction in the sensitivity of the periodontium to CsA. Recently, our group has verified that CsA-induced gingival overgrowth and CsA-induced bone loss in rats are dependent on the duration of treatment. The cellular events involved in the development and regression of CsA-induced gingival overgrowth during the treatment time are not well understood at the moment. They are probably a consequence of disturbances in the homeostatic equilibrium between synthesis and degradation of extracellular matrix molecules or interference in the fibroblast proliferation rates. CsA not only blocks the immune system by means of inhibition signaling through the cell receptor, but also stimulates the production of transforming growth factor $\beta_{1}$ (TGF$\left.\beta_{1}\right)^{4,5,14,16,20,27}$. Several functions have been attributed to TGF- $\beta_{1}$, including the activation of fibroblasts and modulation of matrix protein expression and deposition of matrix protein ${ }^{4,28}$. Therefore, it could be involved in the mechanism of development and regression of CsA-induced gingival overgrowth during treatment. Thus, the purpose of the present study was to investigate the level of TGF- $\beta_{1}$ in saliva and describe the densities of fibroblasts and collagen fibers in the gingival tissue of rats treated with CsA for long periods.

\section{MATERIAL AND METHODS}

Eighty (80) male Wistar rats (Rattus norvegicus albinus) which weighed approximately $50 \mathrm{~g}$ were housed under similar conditions in cages with ac- cess to food and water ad libitum. The animals were randomly distributed into eight groups of ten animals each. Four groups were treated with CsA (Novartis Pharma, Basel, Switzerland), injected subcutaneously in a daily dose of $10 \mathrm{mg} / \mathrm{kg}$ of body weight during the periods of $60,120,180$, and 240 days. According to Wassef et al. ${ }^{24}$ (1985), this dosage provides plasma peak and trough levels of CsA of 1,000 and $750 \mathrm{ng} / \mathrm{ml}$, respectively. Control rats from the other 4 groups were daily injected subcutaneously with saline $(0.9 \% \mathrm{NaCl})$ (Fresenius Kabi Ltda., Campinas, Brazil). All rats were weighed weekly.

\section{Salivation}

The animals were anesthetized with Francotar (Virbac do Brasil Com. Ltda., São Paulo, Brazil)(1.25 g/kg of body weight IP). Salivation was stimulated with pilocarpine $(1 \mathrm{mg} / \mathrm{kg}$ of body weight) injected intra-peritoneally (IP). Ten minutes after pilocarpine (Hexis Científica, Araraquara, Brazil) or saline injection, saliva was collected with a sterile syringe (Injex, Ourinhos, Brazil) $(0.5 \mathrm{ml}$ approximately). All samples were collected between 9 and 11 a.m. and stored at $-20^{\circ} \mathrm{C}$ until assayed for the determination of TGF- $\beta_{1}$.

\section{Enzyme-linked immunosorbent assay (ELISA)}

The levels of TGF- $\beta_{1}$ were measured by ELISA using the kits according to the manufacturer's instructions (Endogen Company, New York, USA). Briefly, diluted saliva samples were added in duplicate to well plates coated with antibody and incubated at $37^{\circ} \mathrm{C}$ for 2 hours. After incubation, each well was aspirated and washed five times with wash buffer. After washing, peroxidase-labeled secondary antibody was added to each well and the plate was incubated at $37^{\circ} \mathrm{C}$ for 1 hour. After each well was washed in a similar manner, the plate was incubated with tetramethylbenzene at room temperature for 20 minutes. The reaction was stopped by adding $1 \mathrm{~N}$ sulfuric acid. Optical density was measured at $450 \mathrm{~nm}$ using a spectrophotometer (Technicon, Domont, France). Sample concentration was assessed by means of a standard curve.

\section{Histology techniques}

The rats were killed by means of an overdose of anesthesia, and their mandibles were carefully removed and soaked in 10\% formalin (Hexis Científica, Araraquara, Brazil). Decalcification was 
Spolidorio LC, Spolidorio DMP, Holzhausen M, Nassar PO, Nassar CA. Effects of long-term cyclosporin therapy on gingiva of rats - analysis by stereological and biochemical estimation. Braz Oral Res 2005;19(2):112-8.

carried out in $4.13 \%$ EDTA solution (Hexis Científica, Araraquara, Brazil) ( $\mathrm{pH} 7.2)$ at $4^{\circ} \mathrm{C}$ for about three months. Five micrometer $(5 \mu \mathrm{m})$ serial paraffin (Hexis Científica, Araraquara, Brazil) sections were made on the bucco-lingual aspects of the left and right $1^{\text {st }}$ molars and stained with hematoxylin and eosin (Hexis Científica, Araraquara, Brazil). Each lower $1^{\text {st }}$ molar had a mesial-distal diameter of about $1 \mathrm{~mm}$, producing about 160 sections of $5 \mu \mathrm{m}$ each. Histometric and stereological studies were made on the buccal gingiva.

\section{Histometry}

Gingival epithelium and connective tissue area measurements were made with the help of a Zeiss microscope (Carl Zeiss, Munich, Germany) at magnification of $125 \mathrm{X}$ using a Sigma computer program (Mocha, Jandel Scientific, CA, San Rafael, USA). From each tooth, 10 measurements in sections of $60 \mu \mathrm{m}$ intervals each were made. For statistical analysis, the mean value obtained for each animal was used, calculated using the 20 measurements obtained from the right and left $1^{\text {st }}$ molars (Figure 1).

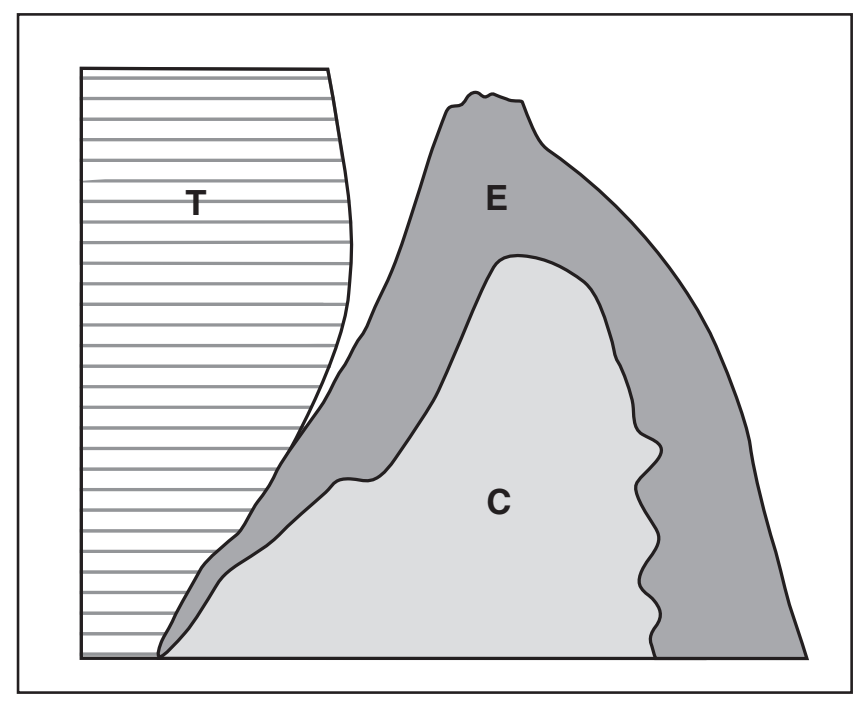

FIGURE 1 - Schematic drawing of area measurements $\left(\mu \mathrm{m}^{2}\right)$ of epithelial tissue $(\mathbf{E})$ and connective tissue $(\mathbf{C})$. (T: tooth).

\section{Stereology}

Volume densities of fibroblasts (Vf), collagen fibers (Vcf) and other structures (Vo), i.e. blood vessels, nerves and unidentified structures, were estimated according to the principles established by Dellesse ${ }^{6}$ (1848), which were applied to histology by Weibel ${ }^{25}$ (1974). The count was performed with the help of a Zeiss microscope, using oil immersion at a magnification of $1,000 \mathrm{X}$. A square lattice of 25 test points was projected into the microscope ocular, with the use of microvid system (Cambridge Instruments Buffalo, New York, USA), which connected the microscope to a computer. For each animal, 16 sections were selected (eight from the left molar and eight from the right one), and 25 points were counted in each section. Vf, Vcf and Vo were expressed as percentages of the total points counted ${ }^{14}$.

\section{Statistical analysis}

Data were expressed as means and standard deviation. ANOVA was used for statistical evaluation. Tukey's test was used to compare differences between groups.

\section{RESULTS}

After 60 and 120 days of treatment with CsA, gingival overgrowth in all animals was observed. Gingival overgrowth was seen in all gingival areas, but it was more evident on the buccal gingival tissue of the lower molar teeth. In all CsA treated rats, the gingival epithelium was hyperplastic, with deep papilla interdigitations. The connective tissue was dense, and showed thick collagen fibers that were interspersed with delicate vessels and fibroblasts. After 180 days of treatment, gingival overgrowth was not observed.

\section{Level of TGF- $\beta_{1}$ in saliva}

The TGF- $\beta_{1}$ levels $(\mathrm{ng} / \mathrm{ml})$ of the control groups and of the groups treated with CsA are demonstrated in Table 1 . The TGF- $\beta_{1}$ level in saliva was significantly higher $(\mathrm{p}<0.05)$ at 60 and 120 days

TABLE 1 - Level ( $\pm \mathrm{SD}$ ) of TGF- $\beta_{1}(\mathrm{ng} / \mathrm{ml})$ in saliva in control groups and groups treated with CsA (Cyclosporin A).

\begin{tabular}{l|c|c|c|c}
\hline \multicolumn{1}{c|}{ Treatment } & 60 days & 120 days & 180 days & 240 days \\
\hline Control & $24.56 \pm 4.39$ & $23.78 \pm 4.44$ & $23.02 \pm 5.11$ & $25.09 \pm 4.11$ \\
\hline CsA & $49.98 \pm 3.26$ & $53.36 \pm 4.19$ & $30.04 \pm 5.56$ & $31.81 \pm 5.41$ \\
\hline \hline
\end{tabular}

SD: standard deviations. 
Spolidorio LC, Spolidorio DMP, Holzhausen M, Nassar PO, Nassar CA. Effects of long-term cyclosporin therapy on gingiva of rats - analysis by stereological and biochemical estimation. Braz Oral Res 2005;19(2):112-8.

of treatment with CsA when compared with control groups (mean values $49.98 \pm 3.26,53.36 \pm 4.19$ and $24.56 \pm 4.39,23.78 \pm 4.44$ respectively). After 180 and 240 days of treatment with CsA, the TGF- $\beta$ l level decreased (mean values $30.04 \pm 5.56$, $31.81 \pm 5.41$ and $23.02 \pm 5.11,25.09 \pm 4.11)$, but levels were not similar to the levels observed in control groups $(\mathrm{p}<0.05)$.

\section{Histometric findings}

Table 2 shows the area $\left(\mu \mathrm{m}^{2} \pm \mathrm{SD}\right)$ of the epithelium and connective tissue of the buccal gingiva of the lower first molars of control and treated rats. The gingiva of control rats showed normal morphology and similar area at all periods of observation. The area values for epithelium and connective tissue were statistically higher $(\mathrm{p}<0.05)$ at 60 and 120 days of treatment with CsA, when compared with control groups. After 180 and 240 days of treatment, the area values of epithelium and connective tissue were still higher when compared with control groups; however, with no statistically significant difference $(p>0.05)$.

\section{Stereometric findings}

Stereometric findings of the control groups and of the groups treated with CsA are demonstrated in Table 3. In the control groups, volumetric densities of fibroblasts, collagen fibers and other structures were, respectively, $11.87 \%, 66.66 \%$ and $21.47 \%$ in the buccal gingiva, and these values remained constant in all the studied periods. The stereometric alterations detected in the treated groups were similar in both gingiva. The volume densities of fibroblasts and collagen fibers increased after 60 and 120 days of treatment with CsA, while the volumetric densities of other structures decreased $(\mathrm{p}<0.05)$. After 180 and 240 days of treatment with CsA, the volumetric densities of fibroblasts and collagen fibers decreased and were similar to values of the control groups, while the volumetric densities of other structures increased.

\section{DISCUSSION}

The present work evaluated the stereological and biochemical changes in gingival tissue following long-term administration of CsA in a well

TABLE 2 - Area $\left(\mu \mathrm{m}^{2} \pm \mathrm{SD}\right)$ of gingival buccal epithelium and connective tissue of the lower first molars of normal rats, which were treated with CsA (Cyclosporin A).

\begin{tabular}{|c|c|c|c|c|c|}
\hline \multirow{4}{*}{$\begin{array}{l}\text { Buccal } \\
\text { epithelium }\end{array}$} & \multirow{3}{*}{$\begin{array}{c}\text { Treatment } \\
\text { Control }\end{array}$} & \multicolumn{4}{|c|}{ Periods } \\
\hline & & 60 days & 120 days & 180 days & 240 days \\
\hline & & $26,520 \pm 879$ & $24,995 \pm 823$ & $25,123 \pm 937$ & $27,951 \pm 866$ \\
\hline & $\mathrm{CsA}$ & $86,098 \pm 991^{a}$ & $99,981 \pm 865^{a}$ & $27,792 \pm 871^{\mathrm{b}}$ & $26,443 \pm$ \\
\hline \multirow{2}{*}{$\begin{array}{l}\text { Connective } \\
\text { tissue }\end{array}$} & Control & $41,503 \pm 1,411$ & $40,903 \pm 1,072$ & $40,882 \pm 962$ & $41,499 \pm 1,211$ \\
\hline & CsA & $149,401 \pm 1,620^{\mathrm{a}}$ & $168,002 \pm 1,811^{\mathrm{a}}$ & $48,441 \pm 707^{\mathrm{b}}$ & $48,691 \pm 874^{b}$ \\
\hline
\end{tabular}

a - Significantly different from corresponding control groups $(\mathrm{p}<0.05) . \mathrm{b}$ - Significantly different from 60 - and 120 -day treatment groups $(\mathrm{p}<0.05)$. SD: standard deviations.

TABLE 3 - Volumetric densities of fibroblasts (Vf), collagen fibers (Vc) and other structures (Vo) in the buccal gingiva region of the mandibular first molar in control and CsA (Cyclosporin A) rats. Values present Means \pm SEM. The results are expressed as percentages.

\begin{tabular}{c|c|c|c|c|c}
\hline \hline \multirow{2}{*}{} & \multirow{2}{*}{ Treatment } & \multicolumn{5}{|c}{ Periods } \\
\cline { 2 - 7 } & & 60 days & 120 days & 180 days & 240 days \\
\hline \multirow{3}{*}{ Vf } & Control & $11.87 \pm 0.3$ & $11.01 \pm 0.2$ & $10.93 \pm 0.4$ & $10.81 \pm 0.2$ \\
\cline { 2 - 7 } & CsA & $13.66 \pm 0.8^{\mathrm{a}}$ & $13.08 \pm 0.5^{\mathrm{a}}$ & $10.99 \pm 0.5^{\mathrm{b}}$ & $10.67 \pm 0.7^{\mathrm{b}}$ \\
\hline \multirow{3}{*}{ Vc } & Control & $66.66 \pm 0.2$ & $66.70 \pm 0.3$ & $65.90 \pm 0.2$ & $68.68 \pm 0.3$ \\
\cline { 2 - 7 } & CsA & $76.20 \pm 1.1^{\mathrm{a}}$ & $74.41 \pm 3.1^{\mathrm{a}}$ & $73.23 \pm 2.9^{\mathrm{b}}$ & $64.45 \pm 3.2^{\mathrm{b}}$ \\
\hline \multirow{3}{*}{ Vo } & Control & $21.47 \pm 0.6$ & $22.29 \pm 0.3$ & $20.17 \pm 0.3$ & $20.51 \pm 0.2$ \\
\cline { 2 - 7 } & CsA & $10.14 \pm 0.9^{\mathrm{a}}$ & $12.51 \pm 1.0^{\mathrm{a}}$ & $14.78 \pm 0.6^{\mathrm{b}}$ & $23.88 \pm 0.9^{\mathrm{b}}$ \\
\hline \hline
\end{tabular}

a - Significantly different from corresponding control groups $(\mathrm{p}<0.05)$. b - Significantly different from 60- and 120-day treatment groups $(p<0.05)$. SEM: standard error of the mean. 
Spolidorio LC, Spolidorio DMP, Holzhausen M, Nassar PO, Nassar CA. Effects of long-term cyclosporin therapy on gingiva of rats - analysis by stereological and biochemical estimation. Braz Oral Res 2005;19(2):112-8.

characterized rat model. The rat has been extensively used to study the effects of CsA in the gingiva, and the resulting overgrowth is similar to that in humans. In fact, the response in rats is more uniform than in humans. There is agreement in the literature about the "risk factors" of gingival overgrowth. In humans, various "risk factors" associated with both the development and expression of CsA-induced gingival changes have been identified and quantified. These risk factors include age, sex, drug variables, concomitant medications, periodontal variables and genetic factors ${ }^{18}$. Elucidation of such factors may help the treatment of "risk patients"18.

On the other hand, as suggested by Kataoka et al. ${ }^{11}$ (2000), many variables are better controlled in rats, such as genetic predisposition, gender, age and dose of CsA. The routes of administration and dosages of CsA that were used in this work gave consistent responses, as described by our group $^{19,21}$ and by other authors ${ }^{20,24}$. All the rats that were used in this experiment responded positively and uniformly to CsA treatment after short periods of treatment (60 and 120 days). In agreement with previous studies ${ }^{11,19,21}$, in our study, gingival overgrowth showed increase of connective tissue and epithelial tissue when compared with control groups. Although the exact mechanisms involved in the development of CsA-induced gingival overgrowth are not well known, there is substantial evidence that this drug acts directly or indirectly on the growth and function of both gingival fibroblasts and collagen fibers via cytokines and growth factors $^{1,2,4}$. Increased TGF- $\beta_{1}$ production has been demonstrated in CsA-induced gingival overgrowth as well as in other fibrotic side effects of CsA-treatment ${ }^{3}$. TGF- $\beta_{1}$ is a multifunctional peptide that regulates diverse biologic activities including cell growth, cell death or apoptosis, cell differentiation, and extracellular matrix synthesis ${ }^{3}$. TGF- $\beta_{1}$ is believed to be a key mediator of tissue fibrosis as a consequence of extracellular matrix accumulation in pathologic states such as hereditary gingival fibromatosis ${ }^{4,5}$ and progressive renal diseases including CsA-induced nephropathy ${ }^{9}$.

In the present study, a significant increase in the volumetric densities of fibroblast and collagen fibers after short treatment periods (60 and 120 days) was verified. These results are in accordance with results reported in the related literature ${ }^{6,25}$ and some previous studies performed by our group ${ }^{19,21}$. However, some authors ${ }^{2,14}$ have not observed increased fibroblast density. Fibroblast heterogeneity remains one of the key factors used to explain the variable response of gingival tissue to the various gingival overgrowth-induced drugs. A genetic predisposition could also influence the metabolism of CsA. All these factors have already been observed in gingival overgrowth established or during its development.

It is important to point out that the purpose of this study was to investigate the level of TGF- $\beta_{1}$ in saliva and describe the densities of fibroblasts and collagen fibers in the gingival tissue of rats treated with CsA for long periods, as compared to other experimental studies with shorter periods of time. Interestingly, in the present work, a gradual time-related improvement was observed, regarding the modifications in gingival volume after longer periods of treatment (180 and 240 days), with decrease in volumetric densities of fibroblasts and collagen fibers. This fact is not well documented in humans and has not been well explored in experimental studies.

Similar results were found by a recent prospective longitudinal study in humans that showed the relevant role of time in reducing gingival overgrowth in heart transplant patients undergoing CsA therapy from 6 to 48 months after transplantation ${ }^{17}$. Recently, Spolidorio et al. ${ }^{20}$ verified that, besides the regression of CsA-induced gingival overgrowth, alveolar bone loss also decreases with time of treatment. Montebugnolli et al. ${ }^{17}$ (2000) suggested that the reduction in gingival overgrowth could be the result of a positive effect of time in reducing the sensitivity of gingival tissue to the hyperproductive effects of CsA, and could be unrelated to a plaque control program.

A time-dependent pattern of gingival overgrowth in Nifedipine-treated animals was also demonstrated by Fu et al. ${ }^{9}$ (1998). In their study, increased gingival dimensions were observed after 3- to 9-weeks of observation interval. However, at longer observation intervals (6- to 9-weeks), it was difficult to demonstrate a further increase in overgrowth. The results of the present work suggest that special attention should be given to the clarification of the mechanisms of action of CsA on fibroblast and collagen fiber proliferation in vitro and in vivo, as well as on protein synthesis and collagenolytic activity, mainly with longer periods of treatment with CsA. To the best of our knowledge, no previous investigation has analyzed the direct effect of CsA on TGF- $\beta_{1}$ levels in rats treated for long periods with CsA. In this case, we have determined that CsA upregulates the production of TGF- $\beta_{1}$ after short periods of CsA therapy and downregulates it after long periods of therapy. 
Spolidorio LC, Spolidorio DMP, Holzhausen M, Nassar PO, Nassar CA. Effects of long-term cyclosporin therapy on gingiva of rats - analysis by stereological and biochemical estimation. Braz Oral Res 2005;19(2):112-8.

Therefore, the present study revealed that there was a correlation between the decrease in fibroblast and collagen fiber volume and the decrease in TGF- $\beta_{1}$ level.

The study presented here revealed that there was a dynamic process in gingival homeostasis capable of altering or modulating fibroblast function and consequently extracellular matrix production after long CsA therapy. The changes in TGF- $\beta_{1}$ levels verified in rats treated for a long period with CsA could modulate MMP1 and MMP2 production and consequently collagen synthesis as well as altered fibroblast proliferation. Elevated expression and production of TGF- $\beta_{1}$ is associated with reduced expression and activity levels of matrix metalloproteinases, in particular MMP-1 and MMP-2, the most important enzymes associated with extracellular degradation and remodeling ${ }^{4}$.

In summary, the results of the present work show that after 60 or 120 days of CsA treatment there was a significant increase in $\mathrm{Vf}$ and $\mathrm{Vcf}$ as well as a significant increase in TGF- $\beta_{1}$. After 180 or 240 days, reduction in gingival overgrowth associated with significant decreases in the level of TGF- $\beta_{1}$, and also decreased Vf and Vcf, were observed. The data presented here suggests that after long-term therapy, the decrease in the level of TGF- $\beta_{1}$ might contribute to an increase in the proteolytic activity of gingival fibroblasts, favoring normal extracellular matrix synthesis ${ }^{4}$. With the application of molecular techniques to analyze other growth factors, we hope that these facts can be better understood, thereby contributing signifi-

\section{REFERENCES}

1. Ares S, Dill RE, Park B, Cutler CW, Iacopino AM. Cyclosporin A upregulates platelet-derived growth factor B chain in hyperplastic human gingiva. J Periodontol 1996;67:271-8.

2. Atilla G, Kutukculer N. Crevicular fluid interleukin-1beta, tumor necrosis factor-alpha, and interleukin-6 levels in renal transplant patients receiving cyclosporine A. J Periodontol 1998;69:784-90.

3. Bauer M, Schuppan D. TGF-beta 1 in liver fibrosis: time to change paradigms? FEBS Lett 2001;502:1-3.

4. Cotrim P, Andrade CR, Martelli-Junior H, Graner E, Sauk JJ, Coletta RD. Expression of matrix metalloproteinases in cyclosporin-treated gingival fibroblasts is regulated by transforming growth factor (TGF)-beta 1 autocrine stimulation. J Periodontol 2002;73(11):1313-22.

5. Cotrim P, Martellli-Junior H, Graner E, Sank JJ, Colleta RD. Cyclosporin A induces proliferation in human gingival fibroblasts via induction of transforming growth factor-beta 1. J Periodontol 2003;74:1625-33.

6. Delesse MA. Procédé mécanique pour determiner la composition des roches. CR Acad Sce 1848;25:544. cantly to clarify the interaction of gingival cells with CsA or products of its metabolism. The studies exploring the pathogenesis of CsA-induced gingival overgrowth in rats do not explore the time factor of treatment with CsA on gingival overgrowth. With the analysis of the regression of CsA-induced gingival overgrowth, its etiopathogenesis can obtain new and outstanding pulse with the analysis of metabolism and cellular behavior. The mechanisms involved in the regulation, synthesis and destination of cellular products, as well as of the external agents that influence the biology of fibroblasts and the action of genetic information in the activities of these cells in the presence of CsA or of other drugs that induce gingival overgrowth can be better understood.

In a near future, the mechanisms involved in the regulation, synthesis and destiny of cellular products will hopefully be known in depth, as well as the external agents that can influence the biology of fibroblasts and the action of genetic information on the activities of these cells in the presence of CsA or other drugs that can lead to gingival overgrowth.

\section{CONCLUSION}

The data presented here suggest that after long-term therapy, a decrease in TGF- $\beta_{1}$ levels occurs, which might contribute to an increase in the proteolytic activity of gingival fibroblasts, favoring normal extracellular matrix synthesis.

7. Dunn CJ, Wagstaff AJ, Perry CM, Plosker GL, Goa KL. Cyclosporin - An update review of the pharmacokinetic properties, clinical efficacy and tolerability of a microemulsion-based formulation (NEORAL) in organ transplantation. Drugs 2001;61:1957-2016.

8. Faulds D, Goa KL, Benfield P. Cyclosporin. A review of its pharmacodynamic and pharmacokinetic properties, and therapeutic use in immunoregulatory disorders. Drugs 1993;45(6):953-1040.

9. Fu E, Nieh S, Hsiao CT, Hsieh YD, Wikesjo UM, Shen EC. Nifedipine-induced gingival overgrowth in rats: brief review and experimental study. J Periodontol 1998;69:765-71.

10. Hefti AF, Eshenaur AE, Hassell TM, Stone C. Gingival overgrowth in cyclosporine A-treated multiple sclerosis patients. J Periodontol 1994;65(8):744-9.

11. Kataoka M, Shimizu Y, Kunikiyo K, Asahara Y, Yamashita K, Ninomiya M, et al. Cyclosporin A decreases the degradation of type I collagen in rat gingival overgrowth. J Cell Physiol 2000;182:351-8. 
Spolidorio LC, Spolidorio DMP, Holzhausen M, Nassar PO, Nassar CA. Effects of long-term cyclosporin therapy on gingiva of rats - analysis by stereological and biochemical estimation. Braz Oral Res 2005;19(2):112-8.

12. Keown PA, Stiller CR. Cyclosporine: a double-edged sword. Hosp Pract (Off Ed) 1987;22(5):219-20.

13. King G, Fullinfaw R, Higgins TS, Walker RG, Francis DM, Wiesenfeld D. Gingival hyperplasia in renal allograft recipients receiving cyclosporin-A and calcium antagonists. J Clin Periodontol 1993;20(4):286-93.

14. Mandarin-de-Lacerda CA. Manual de Quantificação Morfológica, alometria, estereologia. $2^{\text {a }}$ ed. Rio de Janeiro: CEBIO; 1994.

15. Martins RC, Werneck CC, Rocha LA, Feres-Filho EJ, Silva LC. Molecular size distribution analysis of human gingival glycosaminoglycans in cyclosporin- and nifedipineinduced overgrowths. J Periodontal Res 2003;38:182-9.

16. Mohamed MA, Robertson H, Booth TA, Balupuri S, Kirby JA, Talbot D. TGF-beta expression in renal transplant biopsies: a comparative study between cyclosporin-A and tacrolimus. Transplantation 2000;69(5):1002-5.

17. Montebugnoli L, Servidio D, Bernardi F. The role of time in reducing gingival overgrowth in heart-transplanted patients following cyclosporin therapy. J Clin Periodontol 2000;27(8):611-4.

18. Seymour RA, Elles JS, Thomason JM. Risk factors for drug-induced gingival overgrowth. J Clin Periodontol 2000;27(4):217-23.

19. Spolidorio LC, Merzel J, Villalba H, Vargas PA, Coletta RD, Almeida OP. Morphometric evaluation of gingival overgrowth and regression caused by cyclosporin in rats. J Periodontal Res 2001;36:384-9.
20. Spolidorio LC, Spolidorio DM, Houzhausen M. Effects of long-term cyclosporin therapy on the periodontium of rats. J Periodontal Res (in press).

21. Spolidorio LC, Spolidorio DM, Neves KA, Gonzaga HFS, Almeida OP. Morphological evaluation of combined effects of cyclosporin and nifedipine on gingival overgrowth in rats. J Periodontal Res 2002;37:192-5.

22. Spratt H, Boomer S, Irwin CR. Cyclosporin-associated gingival overgrowth in renal transplant recipients. Oral Dis 1999;5(1):27-31.

23. Thomason JM, Seymour RA, Ellis JS. Determinants of gingival overgrowth severity in organ transplant patients. An examination of the role of HLA phenotype. J Clin Periodontol 1996;23(7):628-34.

24. Wassef R, Cohen Z, Langer B. Pharmacokinetic profiles of cyclosporine in rats. Influence of route of administration and dosage. Transplantation 1985;40(5):489-93.

25. Weibel ER. Selection of the best method in stereology. J Microsc 1974;100:261-9.

26. Willrshausen-Zönnchen B, Lemmen C, Schumacher $\mathrm{U}$. Influence of cyclosporine A on growth and extracellular matrix synthesis of human fibroblasts. J Cell Physiol 1992;152:397-402.

27. Wolf G, Thaiss F, Stahl RA. Cyclosporine stimulates expression of transforming growth factor-beta in renal cells. Transplantation 1995;60:718-23.

28. Zhang C, Meng X, Zhu Z, Yang X, Deng A. Role of connective tissue growth factor in renal tubular epithelialmyofibroblast transdifferentiation and extracellular matrix accumulation in vitro. Life Sci 2004;75(3):367-79. 